\title{
Challenges of an innovative economy in the context of the growing competitiveness of the information services sector
}

\author{
Maya Serdarova*1, Irina Galeeva ${ }^{1}$, Danila Egorov ${ }^{1}$, Danil Burkeev ${ }^{1[0000-0002-4440-5718]}$, and \\ Andrey Zheleznov-Lipets ${ }^{1}$
}

${ }^{1}$ Kazan State University of Architecture and Engineering, 420043 Kazan, Russia

\begin{abstract}
In the century of the global information society and innovation economy, the introduction of modern computer and telecommunication technologies in almost all spheres of human life and activities, has led to the formation of a single space using information services. In the context of information development in an innovative economy, information is becoming an increasingly important and integral part of every competitive company. In innovation economics, this component is becoming the subject of the rapid development of communications, telecommunications, computer and information technologies. By increasing information and intellectual abilities in various market spheres of economic activity of companies, an innovative economy increases its competitive advantages and, consequently, its competitive potential, since its elementary composition receives multilateral economic, personnel, organizational and information support. Information services are considered one of the most promising areas of an innovative economy and their further development is based not only on the timely creation, but also on the implementation of innovations.
\end{abstract}

Keywords. Innovations, digital economy, competitiveness, economics, information services, risks, digitalisation, service innovation, innovation activity.

\section{Introduction}

Innovation in the service sector should be associated with a predictable result, leading to changes both within the manufacturing enterprise and in the external environment. Realizing that there is only one constant thing in the world - changes, nowadays many countries are striving to expand the boundaries of the formation of the information society by increasing the activity in the application of innovative developments [1]. For example, an increase in effective demand is accompanied by an increase in requirements for consumer properties of manufactured products, which forces enterprises to expand and update their product range, make appropriate changes in product design, rebuild marketing networks and diversify the range of services in the consumer market [2].

\footnotetext{
*Corresponding author: serdarova222@mail.com
} 
Russia sets ambitious but achievable long-term development goals - ensuring a high level of well-being of the population, strengthening the country's geopolitical role as one of the global leaders determining the world political agenda. The only possible way to achieve these goals is the transition from the economy to an innovative development model with a social focus [3].

The challenges of innovative development lie in ensuring a high level of well-being of the population and consolidating the geopolitical role of the country as one of the leaders determining the global political agenda. The main of the possible ways to achieve these goals is the growth of the competitive sphere of information services.

The Russian economy faces long-term systemic challenges that reflect both global trends and internal obstacles to development. Their range is so wide that in some ways it covers all spheres and areas of economic development [4]. The main sources of threats to the Russian economy at this stage are the risks associated with the accumulation of imbalances in the structure of the economy, primarily in industrial production.

The development of the service sector and increasing its efficiency in meeting the needs of society are directly related to innovation. Also, one of the main indicators of the development of the service sector is the competitiveness of services, which is directly related to the level of innovation at each enterprise [5]. The modern economy is a complex economic mechanism in which various structural elements of a commercial, industrial, informational and financial nature interact, for the proper functioning of which economic transformations are necessary, taking into account the interests of regions and industries. At the same time, at the macro level, regional level and enterprise level, the main efforts are aimed at solving the development of the state innovation strategy, the development and formation of the innovation climate, the implementation of the state innovation program with reference to the specifics of the regions and the level of development of the competitiveness of information services.

\section{Materials and methods}

To accelerate the transition to an innovative path of development, it will take place in the context of the impact on Russia of a number of external and internal challenges, on the one hand, making it difficult to fulfill the assigned tasks. On the other hand, the goals dictate the need for an even greater intensification of efforts to solve the problems accumulated in the Russian economy and the innovation system. The key external challenges in terms of innovative development are.

Table 1. Solving the problems of an innovative economy.

\begin{tabular}{|c|c|l|}
\hline \multicolumn{1}{|c|}{ Tasks } & \multicolumn{1}{|c|}{ Solution } \\
\hline $\begin{array}{c}\text { Distribution and } \\
\text { coordination of } \\
\text { innovation processes }\end{array}$ & $\begin{array}{c}\text { improve the efficiency of } \\
\text { institutions for innovative } \\
\text { development }\end{array}$ & $\begin{array}{l}\text { assistance to authorized bodies in the } \\
\text { management and coordination of } \\
\text { innovation processes }\end{array}$ \\
\hline Service support & $\begin{array}{c}\text { create points of growth for } \\
\text { innovation }\end{array}$ & $\begin{array}{l}\text { - innovative grants; } \\
\text { - technoparks; } \\
\text { - industry design bureaus; } \\
\text { - system of commercialization; }\end{array}$ \\
\hline Financial support & $\begin{array}{c}\text { medium-sized innovative } \\
\text { entrepreneurship }\end{array}$ & $\begin{array}{l}\text { - project financing; } \\
\text { - venture financing; }\end{array}$ \\
\hline $\begin{array}{c}\text { Information and } \\
\text { analytical support }\end{array}$ & $\begin{array}{c}\text { improve the effectiveness of } \\
\text { innovation policy }\end{array}$ & $\begin{array}{l}\text { research in the field of improving } \\
\text { innovation and information services }\end{array}$ \\
\hline
\end{tabular}


In this regard, the challenges of the innovation economy should be based on the general rules of development in the organization of the innovation life cycle, as a process of creating and distributing innovations themselves and approaches to the formation of favourable competitive conditions for its reproduction in the territory.

Innovative activity for the creation of information services is the junction of science and production, while remaining a commercial activity, it can develop as long as there is a demand for this type of activity from entrepreneurs, which means that this area is competitive [6].

The level of novelty that the innovation sector focuses on when creating new technological developments, on the one hand, depends on the state of science, which is the main resource of new knowledge for innovators, on the other hand - on the structure of production in the region, which largely determines the scale and specifics of the demand for innovations (Table 2) [7].

Table 2. The demand for innovations.

\begin{tabular}{|c|l|c|c|}
\hline \multirow{2}{*}{ № } & \multicolumn{1}{|c|}{ Indicator } & Russia & South Korea \\
\cline { 3 - 4 } & & Place in the rating & Place in the rating \\
\cline { 2 - 4 } & Global Innovation Index & 47 & 1 \\
\hline 1 & Human capital and science & 30 & 1 \\
\hline 2 & Infrastructure & 60 & 1 \\
\hline 3 & Business development level & 42 & 1 \\
\hline 4 & Development of technology and knowledge economy & 50 & 2 \\
\hline 5 & Results of creative activities & 60 & 1 \\
\hline
\end{tabular}

From the analysis, it becomes obvious that the competitiveness of the information service is based on the competence of the company, which ensures profit by presenting innovative services to customers using the results of a technological breakthrough.

Consequently, the greater the share of the high-tech sector in the innovation economy, the greater the number of competitive information services will be associated with the creation of a service based on a high degree of novelty and perfection.

Highlighting the environmental, social and economic effects of the innovation economy, it becomes obvious that their achievement depends on the efficiency of using the available reserves on the maximum basis and on achieving a sufficiently high level of investment attractiveness, which in general is the basis for creating a competitive information service [8].

Nowadays, the innovative development of the Russian economy in the context of a constant increase in demand for systematic improvement and simplification, while the exclusivity of information services, highlights the following variability:

- Import-substitution orientation - the absence of grandiose efforts or large-scale thoughts and ideas aimed at innovative development. The main focus of this method of development is aimed at maintaining stability and minimizing the costs of science, innovation and investment in human capital. It is obvious that this will lead to an increase in the dependence of Russian producers of information services on foreign technologies and, as a result, will negatively affect the development and application, as well as the development of new research and development. 
- Focusing on catch-up development and localization of technological competitiveness can be considered as a way to re-equip on the basis of imported technologies and locally stimulate the growth of Russian developments. The method of catch-up development is well known in the examples of Japan, South Korea, Malaysia, Singapore, and, of course, China. It is based on the maximum use of technologies available on the world market, which can be purchased and attracted to the country together with foreign capital. The main advantagesthere is no need to invest heavily in the development of what is already working well. At the same time, the entire range of related services is being implemented - staff training, reducing the time for implementing innovative services, and reducing errors. However, there are also risks - tough competition with a constant increase in labor productivity; the dependence of the innovative economy on imports of equipment and technologies does not exactly accelerate the growth of its own developments.

- The focus on achieving leadership in basic research is based on the significant efforts of the state to modernize the research and development sector while developing the most promising areas, including in the field of information services. Active search for new markets, niches and segments, determine this option as the most expensive.

Competitiveness in this case is not only an opportunity, but also an obligation of the information service manufacturer to increase or maintain the market share, while introducing innovative techniques and technologies. Ordering of actions can be considered as the main condition that promotes the sustainable flow of processes in order to ensure the competitiveness of the information services sector. The solution to the problem of increasing the competitiveness of enterprises in the service sector involves a transition from separate disparate to a set of permanent solutions - to a system of ensuring competitiveness [9].

This system for ensuring the competitiveness of enterprises in the service sector should include: a set of interrelated processes, the formation of innovative behaviour, management infrastructure, where the basis of the relationship of principles is aimed at improving competitiveness. The main goal of this system is to expand the production and sale of competitive services through innovative behaviour.

The main conditions for increasing the competitiveness of information services in our opinion are:

- the speed of adaptation of enterprises in the field of information services to the changing conditions of innovative - behaviour (in procurement, sales, with the growth of competitors, etc.);

strengthening the existing market boundaries or expanding them, as a positive result in the competition.

At the same time, the main conditions for the functioning of the system of competitiveness of the service sector will be:

- improving the quality of services while reducing costs;

- development and strengthening of opportunities to increase the types and volumes of information services provided;

- developing the capabilities of technologies for rapid transition to the production and implementation of new services;

- the development of lean manufacturing and cost savings in the implementation of services.

M. Porter stated that in order to understand the competition and professionalism of the industry, it is necessary to analyze the basic structure of the industry in terms of the five forces: the threat of new entrants, the market power of buyers, the market power of suppliers, the threat of substitution of goods and services, and competition among existing competitors [10].

In accordance with the hypothesis of prevailing demand by S. Linder and the theory of international competitiveness of nations by $\mathrm{M}$. Porter, the main condition for international competitiveness is competitiveness in the domestic market [10]. 
Initially, this is the ability of national companies to compete with other national producers and with multinational suppliers of goods and services in the domestic market. In the future, this is an expansion of the company's national market share [11]. As the world ranking of innovative competitiveness shows (Fig. 1), Russia has a lot to strive for, develop and strengthen its capabilities.

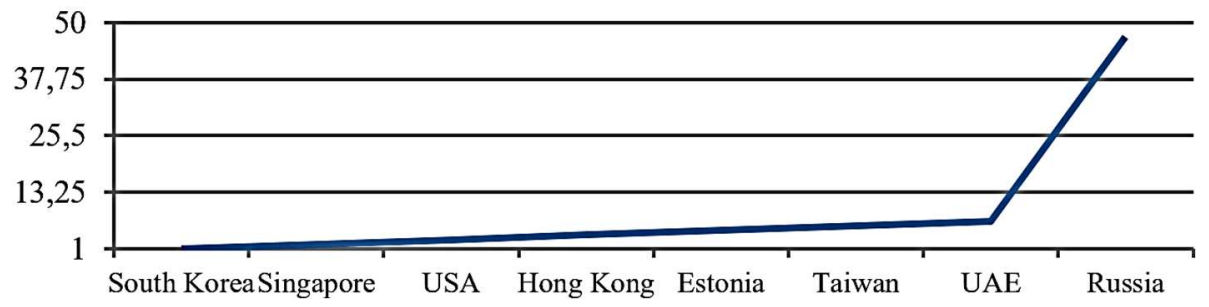

Fig. 1. World Ranking of Innovative Competitiveness.

In the era of globalization of world markets, one of the most important competitive advantages of increasing the competitiveness of information services is the ability to reduce the cost of production.

For example:

- digitalization as a new way of thinking for management and employees (the use of robots is the result of reducing labor costs); at the same time, the robot itself will be considered as an innovative product, and its use as an innovative process that increases the competitiveness of the offered service;

- outsourcing of non-core services - new service markets (logistics costs, legal services, accounting services, etc.) - the result is the release of capital to increase the level of technological productivity.

In addition to reducing the cost of production, the most important competitive advantage in the world markets is the high quality of information services. It becomes obvious that the competitive advantage of an information service is a set of aggregate qualities of this service, which makes it possible to more effectively meet the needs of consumers, in comparison with analogues existing on the market.

\section{Results and discussion}

According to Ivanova I.A. and Kharitonova N.A., the development of digital technologies has undeniable advantages that lead to the active development of all areas of activity, increase comfort, contribute to the rapid updating and promotion of knowledge, the accumulation and development of which is the beginning of innovations in different directions, allows a high level of reliability and transparency of information with various operations. At the same time, due to the lack of supportive measures in the field of education and training and the adaptation of the population to new living conditions in the digital format of socio-economic relations, risks may increase, which causes many socio-psychological problems and can provoke crisis phenomena in society $[12,13]$.

Bagrova N.A. believes that the competitiveness of the innovative economy changes not only the market tactics at the micro level, but also the analog strategy at the macro level of economic entities. It is transformed into a set of innovative actions related to the market of commercial entities for the competitive use of information and intellectual capabilities, aimed at obtaining competitive advantages over their competitors [14]. Such a market strategy implies, first of all, obtaining competitive advantages by increasing the technical level of production and technological mobility of companies, as well as other competitive advantages 
obtained, for example, by improving the quality of marketable products using creative approaches, the opportunities of the skilled labor force, which are the main components of the competitiveness of the innovative economy [15].

Shagiakhmetova E.I., Muharramova E.R., Kafiatullina M.A. believe that the analysis of competitive advantages is an important part of market research, which creates the opportunity to develop a business strategy in the market. The study of competitive advantages includes: studying the experience of successful industries and enterprises; structural analysis of industries; determining the company's position; developing strategic directions for the company's development; determining the company's cost chain to identify opportunities to reduce the cost of production without reducing quality [16].

\section{Conclusions}

Information support of the competitiveness of the innovative economy as a factor direction is characterized by the following information and intellectual features and features:

- it has an intellectual unit in a given information space (information support for innovative types of intellectual or digital activities in any competitive market);

- has a set of information about intellectual types of innovative activities that ensure the competitive functioning of economic entities;

- reflects the cognitive process of creative work;

- creates a new «information product»;

- increases information costs and transfers their cost to the already created naturalmaterial product;

- provides the formation and development of information and intellectual communication between the competitive movement, storage and transmission of information about the competitive intellectual activity of economic entities of the innovative economy;

- identifies the competitive state of information actions of economic entities that improve the competitive environment in innovative markets;

- optimizes the innovative factors influencing the competitive implementation of the information and intellectual strategy for the development of the innovative economy.

The expansion of needs in the service sector leads to the transformation of the production process of raw materials producers, information systems. The development of the service sector creates a new competitive environment and new needs for goods and services [16].

We can say that the innovative process of forming the service sector is adequate to the consumer market, when there is an understanding of the reasons for the appearance, meaning and necessary direction of innovations, the scope of their application, the degree of novelty, the features of the structure of the life cycle, the depth and scale of changes, as well as differences in meeting the needs in certain segments of the consumer market. The modern approach to innovation in the service sector is increasingly based on the consideration of innovation as a process. The focus is on the process of updating and continuous improvement. Process innovation is an important element in the development of a service company.

\section{References}

1. M. Stoyanova. Good Practices and Recommendations for Success in Construction Digitalization, TEM Journal 9. 42-47 (2020).

2. V. Repnikova, O. Bykova, O. Skryabin, D. Morkovkin, L. Novak. Strategic aspects of innovative development of entrepreneurial entities in modern conditions, International Journal of Engineering and Advanced Technology 8, 32-5 (2019). 
3. S. Tyaglov, I. Takmasheva. The use of lean production techniques as the basis of innovative development of regions, Issues of economic regulation 2. 97-110 (2017).

4. O. Belokrylova, M. Vakhtina. Ensuring access of subjects of the social services market to the state order: problems and solutions. State and Municipal Administration. Scientific notes of SKAGS 1, 78-84 (2017).

5. A. Kravets, A. Kashin. Economic interaction between the state and business as a condition for the formation of innovative entrepreneurship in Russia, Creative Economy 2, 161-172 (2016).

6. A. Kashin. Prerequisites and conditions for the introduction of innovative principles to improve the competitiveness of budgetary institutions in the provision of social services, Issues of innovative economy 9, 531-540 (2019). DOI: 10.18334/vinec.9.2.40527.

7. I. Golova, A. Sukhovey. Threats to the Innovative Security of Regional Development in a Digital Society, Economy of region 14, 987-1002 (2018). DOI: 10.17059/2018-3-21.

8. A. Pleslov. Organizational and economic factors of creation and development of industrial parks, Russian Journal of Entrepreneurship 5, 749-759 (2017).

9. A. Poghosyan, K. Kormilitsyn, E. Borkova. Creating the attractiveness of jobs in the digital economy, Creative economy 14, 1311-1324 (2020).

10. R. Fatkhutdinov. Management of the competitiveness of organisation. M. : Market DS, 208 (2017).

11.Y. Vasiliev. Construction industry: time of change, Russian Online Journal «Construction» 9, 56-58 (2020).

12. I. Ivanova. The process of adaptation of personnel in the system of socio-psychological support for the development of the digital economy, Personnel and intellectual resources management in Russia 8 (1), 45-9 (2019).

13. N. Kharitonova, E. Kharitonova, V. Pulyaeva. Prospects for application of new information and communication technologies in contemporary high economic education, Advances in Intelligent Systems and Computing 726, 1091-100 (2019).

14. E. Borkove, A. Izotova, N. Litvinova. Digital transformation of the construction industry amid the COVID-19 macroeconomic shock, Issues of Innovative Economy 10, 2129-2140 (2020). DOI: 10.18334/vinec.10.4.111191.9.

15. N. Bagrova. Development of information economy in Russia under modern conditions/ Bagrova, Scientific Journal «Services in Russia and abroad» 5 (66), 13-20 (2018).

16. A. Kashin, G. Vysotskaya, O. Komarova. Business strategy as a condition for the formation of economic advantages of an economic entity in the sphere of hospitality, Journal of Economy and Entrepreneurship 12, $442-444$ (2016).

17. E. Shagiakhmetova, E. Mukharramova, M. Kafiatullina. Competitive analysis of enterprises of construction materials industry, Russian Entrepreneurship 18, 2153-2169 (2017). DOI: $10.18334 / \mathrm{rp} .18 .14 .38122$.

18. A. Romanova, N. Gareeva, A. Starodubova. The region's competitiveness assessment on the basis of sustainable development, IOP Conference Series 890, (2020). DOI: 10.1088/1757-899X/890/1/012189. 